rzostwie, haniebnym zaparciu i całkowitym opuszczeniu Mistrza przez apostołów w czasie całej jego męki? Słowa ewangelisty (Ek 23, 49): „A wszyscy jego znajomi stali z daleka... patrzac na to" są wyraźną apologią Apostołów.

Ks. B.

\title{
PRZECHOWYWANIE NAJSW. SAKRAMENTU W HISTORII I LITURGII KOŚCIOŁA
}

Zwyczaj przechowywania Najśw. Sakramentu jest tak bardzo dawny, stwierdza Sobór Trydencki, że sięga swymi początkami czasów soboru Nicejskiego, i dlatego należy zachować tę zbawienną i konieczną praktykę na przyszłość ${ }^{1}$ ). Tenże sam Sobór wskazując na starożytność tego "godziwego i rozumnego zwyczaju“ w kan. 7, wyraźnie postanawia: „Jeśliby ktoś powiedział, że nie wolno przechowywać Eucharystii w kościele (in sacrario), lecz zaraz po konsekracji trzeba ją rozdać obecnym, albo że nie należy Jej nosić do chorych z oznakami czci (honorifice), niech będzie wyklęty“" 2).

Powody i sposoby przechowywania Najśw. Sakramentu w ciągu wieków były różne. Początkowo Eucharystii w kościele nie przechowywano. Komunię św. przyjmowali wierni w czasie Mszy św. Kościoły były jednak jeszcze na ogół nieliczne i ciasne; skutkiem tego nie wszyscy wierni mogli brać udział we wspólnej Komunii, tymbardziej, że i kapłanów było niewielu i jedna Msza św., była tylko odprawiana codziennie.

Dlatego też powstał zwyczaj, o którym dowiadujemy się ze świadectw pisarzy chrześcijańskich żyjących w I i II wieku, że Komunii udzielano nie tylko wiernym obecnym na Mszy św., ale także, że Chleb konsekrowany zanoszony był przez diakonów tym, którzy nie mogli przyjść do kościoła ${ }^{3}$ ). Komunię

1) Conc. Trid., sess. 13, de Eucharistia, c. 6 (Canones et Decreta S. Oecum. Conc. Trid., Romae 1904, s. 67). Por. Conc. Niceanum Generale I, c. 13 (Mansi, Sacrorum Con. ...collectio, t. 2, kol. 681).

2) Tamże, Sess. cit., c. VI, can. 7.

3) Por. Koster L., De custodia Sanctissimae Eucharistiae, Romae 1940, s. $8 ; 6$, nota 2 


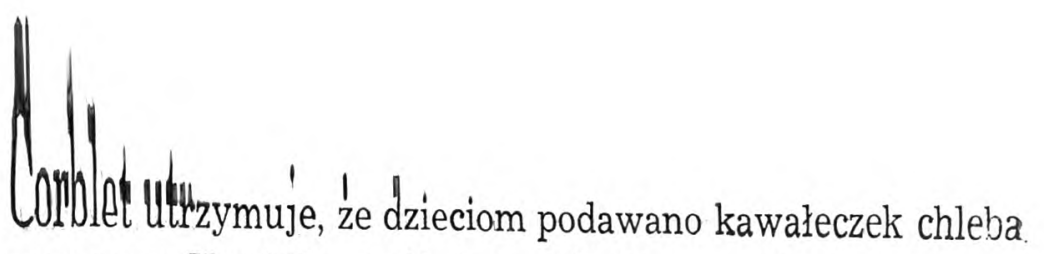
namoczony w Krwj Przenajświętszej 5). Ks. arcybiskup Bilczewski nie podziela tego zdania w oparciu o tekst św. Cypriana, mówiący 0 Komunii pewnej dziewczynki pod postacią wina ${ }^{6}$ ).

Ministrem właściwym Eucharystii był biskup, a W Zästępstwie administrowali Ją kapłani i diakoni jako szafarze nadzwyczajni ${ }^{7}$ ). Prywatnymi szafarzami byli wierni. Otrzymywali oni Komunię na rękę, z tą tylko różnicą, że mężczyznom kładziono święte Postacie na gołą dłoń, niewiastom zaś na płótno (linteamen-chusteczka), zwane „Dominicale“" 8 ).

$\mathrm{Z}$ początku II wieku mamy pewne dokumenty świadczące o tym, że chrześcijanie komunikowali także w niebezpieczenstwie śmierci ${ }^{9}$ ).

Pochodzące z III wieku opowiadanie biskupa Dionizego Aleksandryjskiego o starcu Serapionie, wspomina o Wiatyku udzielonym choremu na łożu śmierci. Starzec ten $\mathrm{w}$ czasie prześladowania zaparł się Chrystusa i został wykluczony z Kościoła, a kiedy był już bliski śmierci, w śmiertelnej chorobie, posłał

4) Por. J. Bilczewski, Eucharystia w świetle najdawniejszych pomników piśmiennych, Kraków 1898, s. 115.

5) Histoire du sacrament de L'Eucharistie I, 305.

$\left.{ }^{6}\right)$ „Ubi vero solemnibus adimpletis calicem diaconus offere praesentibus coepit, et accipientibus caeteris locus eius advenit, faciem suam. parvula instinctu divinae maiestatis avertere, os labiis obturantibus premere, calicem recusare. Perstitit autem diaconus, et reluctanti licet de sacramento calicis infundit. Tunc. De lapsis 25 (Migne, P. L., t. 4, kol. 499, 500.

7) Por. Tertul., De corona mil., e. 3. (Migne, P. L, t. 2, kol. 79).

8) „Omnes viri qui communicar desiderant, prius lavant manus suas; ut mente pura et nitida conscienti. Christi sacramenta suscipiant. Similiter et mulieres nitida exhibeant linteamina, ubi corpus Christi accipiant pura mente et nitida conscientia. Yiris tantum nuda manu sumere concessum, faeminis vero nonnisi linteamine, quod dicebatur Dominicale". C. Baronius, Annales Ecclesiastici, t. I, an. 57, n. 147, 148.

9) Ignatius, Ep. ad Romanos, c. 7, Funk, Patres Apost., I, 260. 
chłopca do kapłana z gorącą prośbą o Wiatyk i absolucję. Chory kapłan nie mógł jednak udać się do umierającego, dał więc chłopcu kawałek Eucharystii z poleceniem, aby umoczywszy nieco w wodzie włożył starcowi w usta. Po przyjęciu Komunii chory skonał ${ }^{10}$ ).

Sobór zaś Nicejski (325), nakazuje już przechowywać Najśw. Sakrament w tym celu, aby chorzy w niebezpieczeństwie śmierci mogli być zaopatrzeni Wiatykiem ${ }^{11}$ ).

Inne świadectwa o przechowywaniu Najśw. Sakramẻntu dla chorych spotykamy także w wiekach następnych.

Podobnie czytamy u Gracjana, że kapłan powinien zawsze przechowywać Eucharystię, aby chorym mógł jej natychmiast udzielić, tak by nikt bez Wiatyku nie umarł ${ }^{12}$ ).

Lecz przechowywanie Eucharystii do komunikowania wiernych i administrowania chorym Wiatyku nie było wyłącznym powodem tej praktyki Kościoła. Sw. Paweł w pierwszym liście do Koryntian pisze: „Chleb, który łamiemy czyż nie jest uczestnictwem Ciała Pańskiego? Dlatego, że jeden mamy chleb, wielu jednym ciałem jesteśmy, wszyscy, którzy w jednym chlebie uczestniczymy ${ }^{613}$ ).

Te słowa natchnione stały się powodem symbolicznego zwyczaju, jaki miał miejsce w pierwszych wiekach Kościoła. Polegał on na tym, że papieże posyłali pasterzom kościołów tytularnych w Rzymie i na przedmieściach, Hostie konsekrowane, których cząstkę wkładali ci do kielicha podczas Mszy św., na znak jedności między Papieżem, duchowieństwem i wiernymi ${ }^{14}$ ).

Dowiadujemy się o tym, między innymi, z listu Ireneusza

10) List do Fabiusza, Eusebius Historia Ecclesiastica VI, 44; Migne P. G., t. 20, kol. 629-633.

11) Por. J. Hefele, Konziliengeschichte, t. I, s. 401; „Die his qui ad exitum veniunt, etiam nunc lex antiqua regularisque servabitur, ita ut si quis egreditur e corpore, ultimo et necessario viatico minime privetur... Generaliter autem omnicuilibet in exitu posito, et poscenti sibi communionis gratiam tribui, episcopus probabiliter ex obligatione dare debebit".

12). C. 93, D. 2 , de consecratione.

13) I Kor., 10, 16.

14) Irenaeus, Ep. ad Victorem Papam, ap. Eusebium, Historia Eccl., V, c. 24; Por. J. Corblet, Histoire du Sacrament de 1'Eucharistie, t. I, 1. XII, c. II, 525 . 
Męczennika z Lyonu († 202) żyjącego za czasów papieża Wiktora (192-202), a które to listy podaje Euzebiusz ${ }^{15}$ ).

Z IV wieku pozostały dwa dekrety papieży Milicjadesa i Syrycjusza, wspominające ogólnikowo o przesyłaniu Chleba konsekrowanego w czasie Mszy papieskiej do kościołów parafialnych.

Zaś papież Innocenty I (w początkach II wieku), w liście do Decencjusza biskupa z Eusebium, powiada, że ponieważ duszpasterze nie mogą w niedzielę opuszczać swoich parafian, otrzymują z oltarza papieskiego Chleb konsekrowany, aby nie czuli się odłączeni od swego biskupa ${ }^{16}$ ). Podobnie i biskupi, którzy nie mogli odprawiać Mszy św., ze swymi kapłanami, posyłali im przez akolitów Chleb konsekrowany, który spożywali kapłani w czasie Mszy św.

Był również zwyczaj przechowywania cząstki konsekrowanego Chleba, w tym celu, by móc włożyć go do kielicha podczas następnej Mszy św., na znak jedności moralnej i ponawiania Ofiary Krzyżowej po wszystkie czasy ${ }^{17}$ ).

Zwyczaj przechowywania Najśw. Sakramentu miał również pewien związek z pewnymi ceremoniami kościelnymi jak rip. przy konsekracji biskupiej i święceniach kapłańskich, przy Mszy Praesanctificatorum, przy obrzędzie konsekracji zakonnic, konsekracji ołtarza, a nawet, jak zobaczymy poniżej, Eucharystie kładziono do trumny zmarłym.

Przechowywano więe Najśw. Sakrament pod 2 postaciami od W. Czwartku do Mszy Praesanctificatorum W. Piątku, która była znana w Rzymie od V wieku. Mówi o tym sakramentarz gelazjański, który zawiera taką rubrykę: "Procedunt cum cor-

${ }^{15}$ ) Eusebius, 1. c., De Eccl. offic., 3, 31; Por. Raible, Der Tabernakel einst u. jetzt, s. 96 .

16) Por. Ks. J. Bilczewski, 1. c., s. 284; Raible, 1. c., s. 96.

17) Były to tzw. ,Sancta“, podczas pochodu ,ad introitum“ jak mówi I Ordo Romanus, przynoszono je Papieżowi, który adorowal Najśw. Sakrament a potem przed „Pax Domini“", wkładał konsekrowaną cząstke do kielicha. (Migne, P. L., t. 78, kol. 937). Por. Raible, 1. c., s. 76; Podobnie czynił celebrujący biskup. 
pore et sangtine Domini quod ante die remansit et ponunt super altare ${ }^{\text {18) }}$ ).

Według opinii Eisenhofera ${ }^{19}$ ) do IX wieku w Rzymie istniał zwyczaj polegający na tym, że w czasie konsekracji biskupiej konsekrowany otrzymywał od konsekratora Hostię, którą następnie ten pierwszy spożywał po cząstce w czasie swej Mszy świętej, przez 40 dni następnych. W ten sposób miała się wyrażać symboliczna jedność między konsekratorem a konsekrowanym ${ }^{20}$ ). Zwyczaj ten był znany również $w$ innych prowincjach Kościoła, gdzie trwał o wiele dłużej.

Także podczas święceń kapłańskich neoprezbiterzy otrzymywali od biskupa udzielającego święceń dużą Hostię, która. spożywali po cząstce przez 40 dni, wkładając do kielicha w czasie Mszy św., na „Pax Domini“. Zwyczaj ten był praktykowany w Rzymie, w niektórych okolicach Niemiec, a zwłaszcza. we Francji ${ }^{21}$ ).

Jeszcze w XI i XII wieku w niektórych klasztorach żeńskich. utrzymywał się zwyczaj polegający na tym, że nowicjuszki otrzymywały dużą Hostię w czasie obrzędu ich konsekracji, a one ją przechowywały u siebie przez osiem dni, codziennie z niej komunikując ${ }^{22}$ ).

W czasie konsekracji ołtarza, oprócz relikwii świętych wkładano również do puszki Najśw. Sakrament, którą następnie umieszczał konsekrator w ołtarzu. Najstarszy dokument jaki posiadamy mówiący o tym zwyczaju pochodzi z IX wieku i za-

18) Sacramentar. Gelasian., I, c. 41; (Migne, P. L., t. 74, kol. 1105); Por. Raible, 1. c., s. 76.

19) L. Eisenhofer, Handbuch der katholischen Liturgik, I, s. 105.

20) Ordo Romanus VIII: „Dum vero venerit ad communicandum, domnus Apostolicus perrigit ei formatam atque sacratam oblationem; et eam suscipiens episcopus ipse ea communicat super altare, et sibi ceterum. ex ea reservet ad communicandum usque ad dies quadraginta. (P. L., t. 78, kol. 1004).

21) Por. Martène, De antiquis Ecclesiae Ritibus, t. 2, 88, 29, 73, 54; Tamże, 24, 51.

$\left.{ }^{22}\right)$ Tamże, t. I, c. V, art. 1, n. 5; Por. Corblet, Histoire de l'Eucharistie, I. 541; Raible, 1. c., s. 99; Art. P. Browe, Jahrbuch für Liturgiewissenschaft 12 (1934), 161-177. 
warty jest $\mathrm{w}$ postanowieniach jednego $\mathrm{z}$ synodów angielskich ${ }^{23}$ ).

Jak wspomniano powyżej, znana była również praktyka kładzenia Najśw. Sakramentu zmarìym do trumny. Dopatrywano się w tym nieraz zwyczajów pogańskich, w myśl których zmarłemu wkładano w usta monetę, by ten mógł zapłacić Archeontowi za przewóz przez Styks. Trzeba raczej przyjąć, że zwyczaj ten był podyktowany troska o zbawienie zmarłego. Należy także zaznaczyć, że praktyka ta nigdy przez Kościól nie była polecana, a nawet stosunkowo wcześnie, bo już w 393 r., została potępiona przez synod w Hipponie. Uzasadnił zaś ten zakaz III synod kartagiński ${ }^{25}$, odbyty w 397 r. Inne, następne synody przypominają ten zakaz. Dodać jeszcze trzeba, że sądzono wówczas błędnie, iż chrztu i Eucharystii można udziela.c nawet zmarłym ${ }^{26}$ ).

Przedstawiwszy powyżej, pobieżnie i szkicowo, powody przechowywania Najśw. Sakramentu, obecnie przejdziemy do miejsca przechowywania Eucharystii, a więc do przechowywania jej poza kościołem, następnie w, kościołach i poszcze-

${ }^{23}$ ) In decretis synodi apud Celychith in Anglia (816), czytamy: „Ubi Ecclesia aedificatur... postea Eucharistia quae ab episcopo per idem mysterium consecratur aliis reliquiis condatur in capsula, ac servetur in eadem basilica. Et si alias reliquias intimare non potest, tamen hoc maxime proficere potest, quia corpus et sanguis est Domini nostri Jesu Christi“. (Can. 2, Mansi, t. 14, kol. 356).

$\left.{ }^{24}\right)$ L. Köster, l. c., s. 18, dodaje: „Primus qui contradicebat inquantum scimus, erat Guidus de Baysio ( $\dagger$ 1313) qui errore quidem utans Cardinalem Hostiensem affirmat iam Innocentium IV (1232-54) hanc praxim prohibuisse, et addit rationem: Corpus Christi esse Cibum animae et non debere servari nisi ad opus infirmorum dictum enim esse: „Accipite et commedite“, et non: ,accipite et conservate" vel "recondite". Alii eius exemplum sequebantur, ad quam reactionem reducendum erit, quod seculis XIV et XV maior pars fontium liturgicorum hanc rubricam omittit, ...Pseudo-reformatione obveniente omnino evanescit".

${ }^{25}$ ) C. 6, Conc. Carthaginiense III, a. 397 (Harduin, t. I, kol. 961: „Item placuit ut corporibus defunctorum eucharistia non detur. Dictum est enim a Domino: Accipite et edite. Cadavera autem nec accipere possunt, nec edere").

${ }^{26}$ ) Por. Corblet, 1. c., I, 339. 
gólnych ich rodzajach, wreszcie o samym sposobie przechowywania św. Postaci.

Srogie prześladowania Kościoła w pierwszych wiekach, przyczyniły się znacznie do powstania zwyczaju zabierania i przechowywania przez wiernych Najśw. Sakramentu w swych domach. Swiadkiem potwierdzającym istnienie tego rodzaju zwyczaju jest Tertulian, żyjący pod koniec II i na początku III wieku.

"Twój mąż, pisze Tertulian do niewiasty chrześcijańskiej, która wyszła za poganina, nie będzie wiedział, co pożywasz skrycie-naczczo, a gdyby chleb zobaczył, to i tak nie będzie miał za to, czym jest w istocie“" ${ }^{27}$ ). Zaś św. Cyprian, biskup kartagiński (249-258), opowiada, że pewna niewiasta, która odważyła się dotknąć przechowywanego w domu naczynia z Najśw. Sakramentem „manibus indignis“ została porażona ogniem ${ }^{28}$ ). Podobnie św. Bazyli potwierdza ten zwyczaj kiedy mówi o tym, że mnisi przebywający w eremach na pustyni przechowują u siebie Najśw. Sakrament, oraz, iż wierni w Egipcie i Aleksandrii przechowuja Go także w swoich domach ${ }^{29}$ ).

Nasuwa się teraz pytanie w jaki sposób, w czym, przenoszono Eucharystię do domów. Trudno na to pytanie dać wyczerpującą odpowiedź, albowiem różna w różnych czasach i miejscach istniała praktyka. Z żywotu św. Tarsycjusza np. dowiadujemy się, że poganie rozwijali jakąś chusteczkę, w której znajdował się ukryty Najśw. Sakrament. Do przenoszenia Najśw. Sakramentu używano często lnianej chusteczki (linteamen-lintoleum), którą później nazywano również „Dominicale", ponieważ Ciało Pańskie na niej składano ${ }^{30}$ ). Według opinii innych autorów używano w tym celu również

$\left.{ }^{27}\right)$ „NNon sciet maritus, quid secrete ante omnem cibum gustes; et si sciverit panem, non illum credit esse qui dicitur". Ad uxorem, 1; II, c. 5. (Migne, P. L., t. I, kol. 1296). Por. De oratione, c. 14. (Migne, P. L., 't. I, kol. 1182-1183).

${ }^{28)}$ De lapsis, n. 92. (Migne, P. L., t. 4, kol. 486).

20) Hieronim., Epist. 50 ad Pammachium; Baronius, 1. c., ad an. 57, n. 151 et ad an. 570.

30) Kraus, Real-Encyklopedie der christlichen Altertümer, Freiburg i. Br. 1882 , I, s. $374-75$; Raible, I. c., s. 85. 
drewnianych naczyń ${ }^{31}$ ). Jeszcze inni utrzymują, że dó domów i w podróży nosili chrześcijanie Najśw. Sakrament w puszkach w kształcie krzyża, lub w naczyniach z brązu, srebra, lub złota. Naczynie takie nazywało się "encopolium“ "32) lub „pectorale". Do tego ostatniego podobną była "bulla". Była to torebka na złotym łańcuszku, noszona przez triumfatorów i dzieci ze znakomitych rodzin rzymskich, jako oznaka rodowa i amulet; chrześcijanom zaś służyła do przenoszenia Eucharystii.

Od św. Ambrożego dowiadujemy się, o zwyczaju pozwalającym na zabieranie Najśw. Sakramentu w podróż. Tak np. brat św. Ambrożego w czasie podróży morskiej miał ze sobą Najśw. Sakrament ${ }^{33}$ ). Także św. Wojciech, bp praski, apostoł Polski, Węgier i Prus w czasie swej podróży misyjnej nosił ze sobą Najśw. Sakrament. W żywocie Adelarda z Troyes, z początku XI w., czytamy, że na okręcie przyjmował Komunię. Sw. Ludwik wracając w roku 1254 z niewoli, otrzymał przywilej od legatów papieskich, na zabranie Najświętszego Sakramentu, ażeby on jak również jego ludzie, a zwłaszcza chorzy mogli komunikować ${ }^{34}$ ). Także kapłani szkoccy i angielscy zabierali ze sobą w podróż Najśw. Sakrament w puszkach zawieszonych na piersiach ${ }^{35}$ ). Podobnie i papieże udający się na dłuższy czas poza obręb Wiecznego Miasta zwykli byli zabierać ze sobą Eucharystię. Wówczas to pochód papieski poprzedzał biały rumak przykryty wspaniałym czaprakiem, który unosił na sobie Sanctissimum w specjalnym dla tego celu sporządzonym tabernakulum podróżnym.

To wszystko należy dzisiaj do historii. Zwyczaj bowiem

s1) Por. Raible, 1. c., s. 86.

${ }^{32}$ ) Kolpos-pierś. Por. Raible, 1. c., s. 86.

s3) ,Ab his divinum illud fidelium sacramentum poposcit. Etenim ligari fecit in orario (sudario) et orarium involvit in collo, atque ita se deiecit in mare non requirens de navis compage resolutam tabulam, cui supermatans iuvaretur, quoniam fidei solius arma quaesierat. Itaque his æe tactum atque munitum satis credens, alia auxilia non desideravit". De excessu fratris sui Satyri, 1. I, c. 43. (Migne, P. L., t. 16, kol. 1304; Por. J. Hefele, 1. c., t. 3, s. 583.

s4) Por. Jahrbuch für Liturgiewissenschaft, 12 (1934), 161-177.

s5) Por. J. Hefele, 1. c., t. 3, s. 583, nota 3. 
przechowywania Najśw. Sakramentu w domach prywatnych i zabierania przez wiernych w podróż jest od wielu dziesiątków lat nie praktykowany w Kościele i zakazany. Zwyczaj taki jest obecnie nie możliwy i niedozwolony bez specjalnego pozwolenia St. Apostolskiej. Papież Benedykt XIV konstytucją „Etsi pastoralis" z dnia 26 maja 1742 r., zakazał przechowywania Najśw. Sakramentu w prywatnych domach i zabierania w podróż ${ }^{36}$ ). Podobnie i Kodeks Prawa Kanonicznego wyraźnie postanawia: "Nikomu nie wolno Najśw. Eucharystii przechowyNać u siebie, ani zabierać Jej w podróż“ ${ }^{37}$ ).

Obecnie, zgodnie z tym co zostało powiedziane powyżej, przejdziemy do przechowywania Eucharystii w kościołach. Nie mamy danych, któreby świadczyły o przechowywaniu Najśw. Sakramentu w pierwszych trzech wiekach w kościele. Dopiero, gdy skończył się okres prześladowań i Kościół wyszedł z podziemi, znikła konieczność i potrzeba przechowywania Eucharystii w domach prywatnych, bo można to było czynić w miejscach publicznych, specjalnie dla kultu bożego poświęconych. Nic więc dziwnego, że Kościół powoli, ale stale za pomoca partykularnych zakazów, zaczyna usuwać dawne zwyczaje. Już w IV wieku napotykamy zakaz zabraniajacy pod klątwą zabierania i przechowywania Najśw. Sakramentu w domach prywatnych ${ }^{38}$ ). Po Edykcie mediolańskim ukazują się rozporządzenia papieskie nakazujące kapłanom odprawiać Msze św., w miejscach na ten cel przez biskupów przeznaczonych ${ }^{39}$ ). Domyśleć się nie trudno, że miejsca te to właśnie kościoły. Istnienie zwyczaju przechowywania w tych kościołach Eucharystii potwierdza w pewnym stopniu Cyryl Aleksandryjski ${ }^{40}$ ). Optatus Milewitanus, wspomina o tym, że donatyści dopuścili się niesłychanej zbrodni, a mianowicie w czasie napadu na kościół, przechowywany tam Najśw. Sakrament

${ }^{36}$ ) Por. Wernz-Vidal, De rebus, Roma 1935, s. 583, nota 23.

37) C. I. C., can. 1265 , § 3.

38) „Eucharistiae gratiam si quis probatur acceptam in ecclesia non sumpsisse, anathema sit in perpetuum. Ab universis episcopis dictum est: Placet". C. 3; Conc. Caesaraugustanum 2, 381; (Mansi, t. 3, kol. 634).

39) Por. Köster, 1. c., s. 26-28.

${ }^{40}$ Epist. ad Colosyrium (Migne, P. L., t. 76, kol. 1075). 
porzucili psom ${ }^{41}$ ). Zwyczaj przechowywania Eucharystii w kościołach potwierdza także list św. Jana Chryzostoma do papieża Innocentego, z którego dowiadujemy się o wtargnięciu do kościoła w Konstantynopolu żołnierzy, w czasie udzielania sakramentu chrztu w W. Sobotę. Nie uszanowali oni nawet miejsca przechowywania Najśw. Sakramentu, rozlewając przy tym Krew Przenajświętszą ${ }^{42}$ ). W wiekach następnych spotykamy już coraz liczniejsze dowody świadczące o przechowywaniu św. Postaci w kościołach ${ }^{43}$ ).

Stosunkowo wcześnie bo już na przełomie VIII i IX wieku, znany jest podział kościołów, według którego jedne $\mathrm{z}$ nich mają obowiązek przechowywania Eucharystii, inne kościoły moga to czynić, ale nie muszą, inne zaś nie powinny przechowywać św. Postaci. Nie normowało jednak tej sprawy jakieś prawo ogólne, lecz były to raczej pewne zasady zwyczajowe. $Z$ reguły przechowywanie Najśw. Sakramentu było obowiązkiem kościołów parafialnych, sprawujących duszpasterstwo, $z$ racji administrowania Wiatyku chorym ${ }^{44}$ ). Inne kościoły, jak to zobaczymy jeszcze później, mogły przechowywać Eucharystię na podstawie niepamiętnego zwyczaju, lub indultu St. Apostolskiej. Kościoły katedralne początkowo były równocześnie kościołami parafialnymi, dlatego nie dziwi nas fakt, że w nich spotykamy przechowywaną Eucharystię. W Dekretała.ch Grzegorza IX czytamy, że obowiązkiem archidiakona, między innymi, było czuwać nad tym, by przechowywano Eucharystię w dostatecznej ilości dla chorych ${ }^{45}$ ). Z tekstu wynika, że chodzi tu o kościoły katedralne ${ }^{46}$ ). Kościoły te chociaż nie zawsze były równocześnie parafialnymi, to jednak nie

41) De schismate Donatistorum, 1, II, n. 19 (Migne, P. L., t. 11, kol. 872).

42) Epist. ad Innocentium Papam, n. 3 (Migne, P. L., t. 52, kol. 533): „Neque hic rerum finis erat. Nam et locum in quo sancta condita servabantur, ingressi sunt milites, quorum aliquos scimus nullis initiatos mysteriis et viderunt omnia quae intus erat. Quin et sanctissimus Christi sanguis sicut in tali tumultu contigit, in praedictarum militum vestes effusus est".

43) Por. Köster, 1. c., s. 30-33.

${ }^{44)}$ c. 93, D. 2 , de consecr.

45) c. $3, X, I, 24$.

46) Wernz, Jus Decretalium, III, n. 549. 
odmawiano im prawa do przechowywania św. Postaci, uważając je jako „prima parochia dioecesis“. Także liczne wypowiedzi Kongregacji, a między innymi i Kongregacji Obrzędów, suponują możliwość przechowywania Eucharystii w tych kościołach ${ }^{47}$ ).

Jeżeli chodzi o kościoły parafialne to te miały nie tylko prawo, ale i obowiązek przechowywania Najśw. Sakramentu; w nich też spełniano posługi duszpasterskie, udzielano sakramentów św. ${ }^{48}$ ) Dlatego kościoły te nie mogły się uwolnić od tego obowiązku i nie miał tu znaczenia zwyczaj przeciwny, ani też bliskość innego kościoła, gdzie przechowywano Eucharystię. W kościołach filialnych z racji zleconego duszpasterstwa można było przed Kodeksem przechowywać Najśw. Sakrament. Pozwolenie tego rodzaju suponuje odpowiedź św. Kongregacji Obrzędów z dnia 15 listopada $1890 \quad$ r. $^{49}$ )

Przechowywanie Eucharystii w kościołach zakonnych jest zwyczajem bardzo starym, sięgającym swymi początkami VI wieku $\left.{ }^{50}\right)$. Nie było jeszcze w tym czasie przepisów Kościoła $\mathrm{w}$ tej materii, dlatego też praktyka ta stała się powszechna w kościołach zakonnych. Według wymogów starego prawa kościoły należące tak do zakonów męskich jak i żeńskich mogły stale przechowywać Najśw. Sakrament, ze względu na możność udzielania. Wiatyku chorym przebywającym w klasztorze, na podstawie ogólnego pozwolenia ${ }^{51}$ ). Z tego prawa korzystały według dekretu św. Kongregacji Obrzędów z dnia 16 kwietnia 1644 r., kościoły i kaplice publiczne zakonnic, lecz wtedy tylko, jeżeli zakonnice nalcżały do zakonu zatwierdzonego przez St. Apostolską i jeżeli żyły w kanonicznej klauzurze. W kościołach lub kaplicach zakonnic tworzących tylko tzw. kongregacje np. Szarytki nie wolno było przechowywać Najśw. Sakramentu. Co do innych kościołów i kaplic to Ordy-

47) SRC., 23 martii 1593, n. 31; 6 febr. 1875, n. 3335.

19) Por. Browe, Die Verehrung der Eucharistie im Mittelalter, München 1933, s. 24; Sobór Later. IV (1215) nakazał przechowywanie Eucharystii w całym Kościele. (Mansi, l. c., t. 22, kol. 1007).

49) D. 3739, ad 1; Gasparri, De SS. Eucharistia, Parisiis 1885, II, 974.

${ }^{\text {sө) }}$ Köster, 1. c., s. 61-63.

•1) Gasparri, 1. c., II, n. 978. 
nariusz miejsca decydował, czy można tolerować zwyczaj niepamiętny. W konstytucji „Quamvis iusto" z dnia 30 kwietnia 1749 r., Benedykt XIV stanowi ogólną regułę, że nie wolno przechowywać Eucharystii w kościołach nie parafialnych, bez indultu St. Apostolskiej 52). Pod jakimi warunkami dozwolone było przechowywanie Najśw. Sakramentu, pouczał dekret św. Kongregacji Obrzędów z dnia 23 marca 1593 r. ${ }^{53}$ ).

Wreszcie na zakończenie, jeszcze o sposobie przechowywania Najśw. Sakramentu. Nie zawsze bowiem przechowywano Go na ołtarzu w kościele, a tym bardziej w tabernakulum jak to widzimy dzisiaj. Początkowo przechowywano Eucharystię W Pastophorium ${ }^{54}$ ). Pastophorium, sanctarium, secretorium, conditorium, diaconicum, to nazwy miejsca przechowywania Najśw. Sakramentu. Diaconicum była to mała absyda po lewej stronie głównego ołtarza, gdzie oprócz Eucharystii przechowywano księgi Ewangelii. Po stronie przeciwnej znajdowało się secretorium przeznaczone na wino i chleb, dary składane na ofiarę. Diaconicum i secretorium razem wzięte nazywano pastophorium ${ }^{55}$ ). W małych kościółkach (basiliculae) bez bocznych pomieszczeń, Najśw. Sakrament umieszczano za lub obok ołtarza w niszy mieszczącej się w ścianie. Najstarsze takie tabernakulum ścienne $\mathrm{z}$ V wieku, odkrył archeolog francuski Rohoult de Fleury w Spoletto (Włochy), w małym kościółku SS. Aniołów ${ }^{56}$ ).

Jeden z najstarszych dokumentów pochodzący z VI w., wspomina już o przechowywaniu Eucharystii w kościele na ołtarzu. Dowiadujemy się o tym z postanowień synodu w Tours

52) Gasparri, Codicis Iuris Canonici Fontes, t. 2, n. 398.

53) „Ex speciali gratia posse concedi, ut in eccl. etiam quod non sit aathedralis, neque parochialis... sed simplex in locis... possit asservari Eucharistiae Sacramentum, de consensu ordinari... dummodo ecclesia ipsa sit decens... habeat beneficiatum perpetuum, qui eius curam geret et Sacramentum caute possit custodiri, et ibi lampas perpetuo accensa habeatur".

${ }^{54}$ ) Pastophorium - miejsice tajemne, ukryte.

s5) Por. Raible, 1. c., s. 64-66.

${ }^{58)}$. La Messe (études archeologiques sur les monuments, Paris $1883-1889)$. 
(567), który poleca przechowywać Najśw. Sakrament na ołtarzu, a nie w szafce (in armario) ${ }^{57}$ ). Przechowywano też Eucharystię nad ołtarzem w zawieszonym tzw. gołąbku eucharystycznym, kiedy indziej znowu w wieżyczce eucharystycznej, a później coraz częściej na ołtarzu ${ }^{58}$ ).

W V wieku ołtarze zdobi już ciborium i tam też zawiesza się św. Postacie przy pomocy łańcuszka nad ołtarzem. Dzisiejsza nazwa ciborium jest późniejszego pochodzenia i nosi nazwę puszki. Wspomniəne goląabi eucharystyczne wykonywano ze złota, srebra lub miedzi. Te ostatnie złocono wewnątrz i na zewnątrz. Zaznaczyć należy, że zwyczaj używania tych gołąbków nie był zbyt rozpowszechniony. Spotykamy go głównie w północnej Francji, Belgii i Anglii, w przeciwieństwie do Niemiec, gdzie przeważają znacznie tzw. domki eucharystyczne (Sacramentshäuschen). Zwyczaj zawieszania przechowywanej Eucharystii w Anglii przetrwał do czasów rewolucji religijnej, a we Francji do naszych czasów na mocy specjalnej dyspensy św. Kongregacji Obrzędów, po ogłoszeniu Kodeksu. Mowa tu o katedrze Amiens we Francji. W każdą pierwszą niedzielę miesiąca dokonuje tam diakon w sposób uroczysty zmiany Hostii w gołąbku eucharystycznym w asyście 4 kanoników kapitulnych ze świecami, klęczących u stopni oitarza. Szczupłość owych gołąbków wskazuje na to, że nie używano ich do przechowywania Najśw. Sakramentu, lecz raczej służyły dla wystawienia i adoracji św. Postaci, stając się do pewnego stopnia

$\left.{ }^{57}\right)$ Por. Schmid, Der christliche Altar, s. 109; Wynika to także z homilii pap. Leona IV (847-855); (Migne, P. L., t. 115, kol. 677-678; P. L., t. 132, kol. 456). Papież Leon IV mówi, że na ołtarzu nie może nic się znajdować prócz relikwii, Ewangelii i puszki z Eucharystią, jako Wiatyk. Podobnie Regino z Prüm († 915) w czasie wizytacji pasterskiej wymaga, by Eucharystię przechowywano na oltarzu. De ecolesiasticis disciplinis, 1, I, n. 9. (Migne, P. L., t. 132, kol. 187). Por. Otte, Archeologie, I, s. 141; Kraus Real-Encyklopedie, art. Taube.

${ }^{58)}$ Po raz pierwszy przechowywanie Eucharystii na ołtarzu zostało nakazane w 1196 r.: "In pulchriori parte altaris cum sumnia diligentia et honestate sub clave sacrosanctum Corpus Domini custodietur" (Harduin, 1. c., t. 4, kol. 1939). Od XIII wieku Kościól stale przypomina dawne postanowienia o przechowywaniu Najśw. Sakramentu na ołtarzu. W ślad za soborem Lateraneńskim IV (1215), idą synody prowincjonalne. 
zaczątkiem monstrancji. Przechowywanie Eucharystii w naczyniach wiszących stawało się coraz bardziej niepraktyczne i niewygodne zwłaszcza po soborze Trydenckim, kiedy wierni coraz częściej zaczęli przystępować do Komunii św.

Kolebka tabernakulum ołtarzowego w dzisiejszym znaczeniu jest Francja, a właściwie diecezja wielkiego biskupa z Tours, św. Marcina ${ }^{59}$ ). W Niemczech tego rodzaju tabernakula służące do przechowywania Najśw. Sakramentu pojawiają się od XIV wieku. Niezależnie od tego jeszcze w XV wieku w kościołach na terenie Niemiec i Belgii często wznoszono domki lub wieżyczki w stylu gotyckim, po stronie ewangelii w prezbiterium, i tam przechowywano św. Postacie ${ }^{60}$ ).

Ogólny ruch w kierunku wprowadzenia tabernakulów ołtarzowych wyszedł z Włoch, z Werony. Jeszcze przed soborem Trydenckim bp Jan Mateusz Giberti (1524-1543) w swej katedrze umieścił Eucharystię na głównym ołtarzu i zalecił taki sposób przechowywania dla swojej diecezji ${ }^{61}$ ). We Francji bp Wawrzyniec z Grenoble († 1561) z racji wizytacji poleca w diecezji przechowywanie Eucharystii na ołtarzu ${ }^{62}$ ). Ogólnie mówiąc wiek XVI daje nam juz obfite wzory dzisiejszego tabernakulum ${ }^{63}$ ). $\mathrm{Na}$ terenach polskich w niektórych kościołach spotykamy również w prezbiterium, w zakrystiach ślady i dowody przechowywania tamże Najśw. Sakramentu, wraz z pięknym, klasycznym i zabytkowym tabernakulum zbudo-

${ }^{59}$ ) Por. Braun, Der Christliche Altar, München, 1924, s. 582.

${ }^{60}$ Coś podobnego spotkać można było w Polsce na początku XVII w. Wieżyczkę zastępowała pyxis, większa puszka często zwana tabernakuhum, wewnątrz tej puszki był rozwinięty korporał, na nim mniejsze naczynia (vascula), także wysłane płótnem, a w nich dopiero płócienne woreczki z Najśw. Sakramentem. To wszystko razem zamknięte było w szafce zwanej tabernakulum lub ciborium. Cyboria były umieszczane przeważnie z boku głównego ołtarza. Wizytatorzy w początkach XVII w., polecają przenosić tabernakulum na ołtarz. (Por. Nowowiejski, Encyklopedia Kośc., t. 3, s. 546-549).

61) "Tabernaculum ligneum aut ex alia materia pulchrum cum sua clavi fiat et super altari magno collocetur et ita bene et firmiter stabiliatur, ut inde per sacrilegos manus avelli nullo modo possit". (Por. J. Braun, l. c., s. 590).

02) Por. Braun, l. c., 591.

63) Eph. Liturgicae, XXXVI, s. 279. 
wanym w XVI wieku na sposób zachodni, w kościele Mariackim $\mathrm{W}$ Krakowie ${ }^{64}$ ).

Sobór Trydencki nie określił również bliżej miejsca przechowywania Najśw. Sakramentu ${ }^{65}$ ), mówiąc tylko ogólnie, że w "Sacrarium" należy przechowywać Eucharystię. Mimo to od czasów tegoż soboru uwidacznia się dążność do ujednostajnienia praktyki przechowywania konsekrowanych Postaci. Przyjmuje się i rozpowszechnia tabernakulum w kształcie szafki przytwierdzonej do środka oltarza. Ostatecznie tego rodzaju tabernakulum zostało przepisane i nakazane przez Rytuał Rzymski w 1614 r., a od czasów papieża Benedykta XIV wymagane jest pozwolenie St. Apostolskiej na przechowywanie Najśw. Sakramentu poza ołtarzem ${ }^{63}$ ).

Kraków

Ks. TADEUSZ SZWAGRZYK

\section{NIEZNANE POLSKIE TEKSTY RELIGIJNE z biblioteki św. Jakuba w Nysie (z XVI w.).}

W Bibliotece Kapitulnej w Wrocławiu ocalał szczęśliwie w czasie ostatniej wojny światowej rękopis, pochodzący z byłej Biblioteki Parafialnej przy kościele św. Jakuba w Nysie, dzięki temu, że na okres oblężenia Wrocławia był wywieziony poza miasto.

Rękopis pochodzi z XVI wieku, pisany jest w języku łacińskim, zawiera też dodatkowe teksty polskie, wymiary ma $10 \mathrm{~cm} \times 15 \mathrm{~cm}$, kart. 141, oprawiony jest $\mathrm{w}$ deskę i skórę, na przedniej okładce wyciśnięta i złocona postać św. Jana Chrzciciela, tylna zaś ma tłoczone i złocone wzory kwiatowe, oprawa na grzbiecie jest nieco uszkodzona, brak zapinek.

Rękopis ten ma tytuł podany w majuskułach: „C ursus de beata Virgine Maria".

64) Por. J. Danielewicz, Kościół i jego wnętrze, Kielce 1948, s. 75.

65) Conc. Trid., sess. 13, c. VI. (Canones et Decreta Oecumenici Concilii Tridentini, Lipsiae 1887, s. 67).

6) Benedictus XIV, in Const. Accepimus 16 Iulii 1746; (Gasparri, 1. c., II, n. 368). 